\title{
Working with Water in Cotton; Developing Water Scouting Strategies at Farm Level
}

\author{
Ghulam Ali*, Qamar Zia \\ CABI Central \& West Asia, Opposite 1-A, Data Gunj Baksh Road, Satellite Town, Rawalpindi, 46000 -Pakistan \\ *Corresponding author: g.ali@cabi.org
}

Copyright (C) 2014 Horizon Research Publishing All rights reserved.

\begin{abstract}
Irrigation has been described as one of the most subsidized activity in the irrigated agriculture in Pakistan. The farmer's thinking about the canal water is as, a free commodity. The farmers observed the scheduled irrigation on weekly basis in cotton without knowing the cost and its impact on cotton crop. This study was conducted to empower the farming communities in developing and adoption of water scouting strategies at farm level in cotton ecosystem which resulted in enhanced water use efficiency and the number of irrigations was cut down up to $33.4 \%$ without affecting the seed cotton yield.
\end{abstract}

Keywords Cotton, Farming Community, Water Scouting

\section{Introduction}

The significance of protecting the water resources around the globe cannot be overstated. In environmental terms, water is the life blood of the planet. Without a steady supply of freshwater, all life, including human would cease to exist. In 1994, the General Assembly of the United Nations forced the international community in resolution 49/103 to put food and agricultural development high on the development agenda and to mobilize resources at national, bilateral and multinational levels in support of sustainable agriculture and food security in developing countries. The General Assembly recognizes that availability of freshwater resources is the prerequisite for economic growth and sustainable development in developing countries. [1].

FAO's recent report on World agriculture: towards 2015/30 highlighted that global food production will need to increase by $60 \%$ to overcome nutrition gaps, deal with the population growth and accommodate changes in diets over the next three decades. Water withdrawals for agriculture are likely to increase by some $14 \%$ in that period, representing an annual growth rate of $0.6 \%$, down from $1.9 \%$ in the period 1963-1999. Much of the increase will take place on irrigated land, forecast to expand globally from some 2 million sq. $\mathrm{km}$ to 2.42 million sq. $\mathrm{km}$. In developing countries, water use efficiency in irrigation is expected to grow from an average $38 \%$ to $42 \%$ [2].

Pakistan, a water-surplus country in the past, is now a water-deficit country. The per capita water availability in Pakistan is about 1,038 cubic meters and below 1,000 cubic meters is a state of chronic water stress. Table 1 gives the comparison of per-capita water availability in some selected countries of the world including Pakistan [3].

Table 1. Per Capita Water Availability in Selected Countries (cubic meter).

\begin{tabular}{|c|c|c|c|}
\hline Country & 1955 & 1990 & 2025 \\
\hline China & 4,597 & 2,427 & 1,818 \\
\hline Mexico & 11,396 & 4,226 & 2,597 \\
\hline Philippines & 13,507 & 5,173 & 3,072 \\
\hline Iraq & 18,441 & 6,029 & 2,356 \\
\hline USA & 14,934 & 9,913 & 7,695 \\
\hline Pakistan & 2,490 & 1,672 & 837 \\
\hline
\end{tabular}

Source: Population Action International, 1997

Pakistan's situation indicates that the country is nearing conditions of chronic water stress. The extended drought during the recent years reduced the freshwater supplies of the country, which has highlighted the importance of adopting water conservation measures for extremely judicious use of the finite quantity of water.

Cotton is the high delta crop after rice and sugarcane and it takes the biggest share of freshwater in the cotton growing areas [4].

This study was conducted to develop innovative water management tools at farm level and empower the farming communities in efficient use of water resources in cotton ecosystem.

\section{Objectives}

1. To develop water scouting strategies at farm level.

2. To identify and adopt the sustainable water management practices with long term benefits for 
water resources.

3. To empower the farming community in the rationale use of water in cotton.

\section{Methodology}

One Training of Facilitator (ToF) comprising of 31 participants based at Vehari and 12 Farmer Field Schools (FFS) each having 20-25 farmers, were established in the Vehari, Burewala and Mailsi tehsils of district Vehari. Twenty-eight ToF participants were Field Assistants of the district agriculture extension department, two were from the Caritas Pakistan (NGO) and one was the MSc Agriculture student. The ToF participants were divided in to six working groups (each group comprising five ToF participants). The groups were named as;

1. Khushal group

2. Moawan group

3. Zardad group

4. Zarkhaiz group

5. Neghaban group

6. Dehqan group

Two cotton plots were selected at Govt. Seed Farm Vehari, one farmer practice (FP) and the other Integrated Water Management (IWM) plot.

All the inputs regarding irrigation, fertilizer, agronomic practices and pest management decisions in the IWM plot were maintained by the ToF participants. The irrigation requirements of the IWM plot was observed on the basis of when to irrigate? keeping in view the water scouting strategies (developed by the farmers and trainer during the brainstorming session) as follows;

a) The cotton leaves showing water stress at 9-10 a.m.

b) Less soil moisture near the cotton plant below 5-6 inches.

c) Flower appearance at the top portion of the cotton plant.

d) Inter-nodal distance of the cotton plant decreases.

e) Reddish / pinkish streak on the main stem reaches 5-6 inches below the top during early growing season.

f) The upper tender shoot of cotton plant does not break up easily.

The threshold of these water scouting strategies was observed as; when three of the above stages reached, the cotton field should be irrigated (Groups decision).

At each FFS site two cotton plots (FP and IWM) were selected. The IWM plot was maintained (in irrigation, fertilizer, agronomic practices and pest management) by the FFS participating farmers while the FP plot was maintained by the concerned farmer through conventional crop management techniques.

\section{Farmer and Experimentation}

Farmer and science is the experiential learning by the farming communities. Framer is a scientist who does experiments regularly since he is in farming, at his own farm on various aspects of agricultural activities. When a question was asked to the farmers; do they know any impact of water on cotton crop? the answer was yes. If there is less irrigation, the crop dried up and ultimately less yield, and if apply water regularly then there is more yield. They were asked how we could save water in cotton. The answer was if we cultivate on bed and furrow and irrigate at proper time. Then they were asked how they knew the water saving in bed and furrow and proper time of irrigation. The answer was less time for irrigation in bed and furrow as compared to flat/line sowing, having the same source of irrigation (canal / tube-well) in both cases. And about the proper time of irrigation (when to irrigate), they don't have any answer. Now to setup the easy understandable water trial, the farmers were facilitated in;

1. When to irrigate by following the water scouting strategies.

2. Just to keep the watch in their hands at the time of irrigation to IWM plot and find out the time of water application from the same source of irrigation either the plot was planted on bed and furrow or in flat/line sowing.

\section{Results}

In the IWM plots, managed by the participating FFS farmers at all the sites, the irrigation application decisions were made by following the water scouting strategies while the irrigation application decisions in the FP plots were made by the concerned farmers (non FFS participating farmer). The detail of irrigation applications and seed cotton yield in the IWM and FP plots at all the FFS sites in Vehari are presented in Fig. 1 and Fig. 2 respectively.

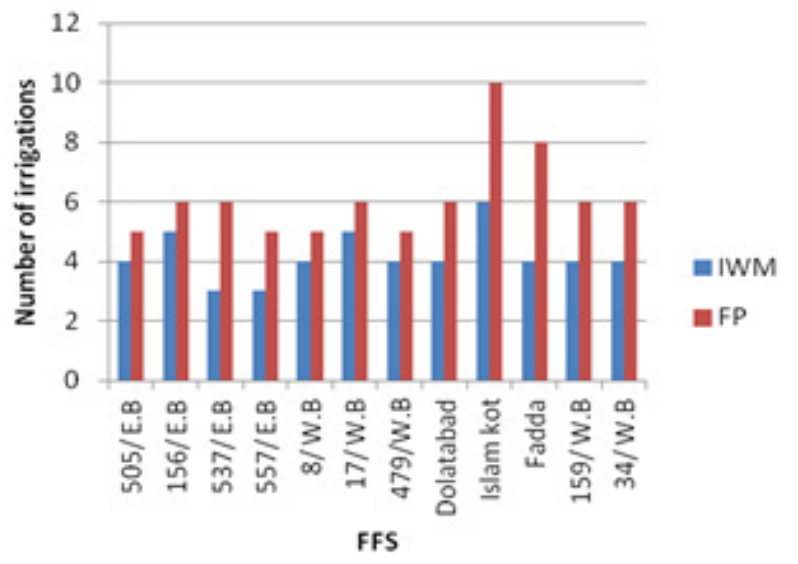

Figure 1. Number of irrigations in FFS plots at Vehari

The results showed that the number of irrigations in all the FP plots were high as compared to the IWM plots where the water scouting strategies were adopted. In the FFS, Islam Kot and 479 /E.B, where both the IWM and FP plots were planted on bed and furrow, the number of irrigation 
applications were six and four in the IWM plots respectively while in the FP plots it were ten and five respectively. In the FFS Fadda the IWM plot was planted on bed and furrow while the FP plot was line/flat sown. The number of irrigations in the IWM plot was four while eight in the FP plot.

In the FFS Islam Kot where both IWM and FP plots were planted by bed and furrow method, the yield in both the plots was almost same even by applying more irrigations and pesticides in the FP plot. In the FFS site at Fadda where the IWM plot was planted on bed and furrow while the FP plot was line/flat sown the yield was high (80kg more) in the FP plot than the IWM plot. The number of irrigations was more in the FP plot than the IWM plot. In Dolat abad both the IWM and FP plots were line/flat sown, the cotton yield was high (70kg more) in the IWM plot than the FP, even by applying more number of irrigations.

The benefit / cost ratio is presented in Table 2 and it was observed that in all the IWM plots, the benefit/cost ratios were higher than the FP plots even by applying more number of irrigations and other farm inputs.

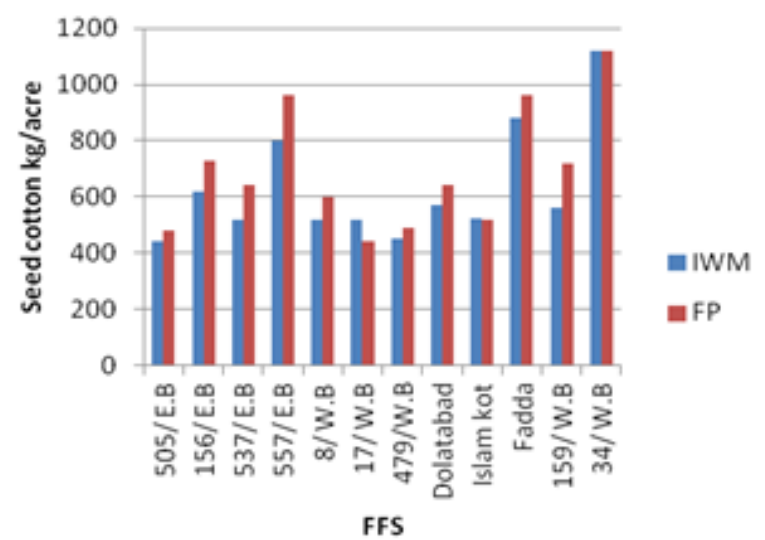

Figure 2. Seed cotton yield in FFS plots at Vehari

Table 2. Cost (on acre basis) of different farm inputs, net income and benefit cost ratio of the IWM and FP plots in FFS at Vehari based on the number of irrigations.

\begin{tabular}{|c|c|c|c|c|c|c|c|c|}
\hline FFS & Plot & $\begin{array}{l}\text { Irrigation } \\
\text { cost* }\end{array}$ & $\begin{array}{c}\text { Spray } \\
\text { Cost } \\
* *\end{array}$ & $\begin{array}{l}\text { Agronomic practices \& } \\
\text { fertilizer cost }\end{array}$ & $\begin{array}{l}\text { Total cultivation } \\
\text { cost }\end{array}$ & Income*** & $\begin{array}{c}\text { Net } \\
\text { income }\end{array}$ & $\begin{array}{l}\text { Benefit } / \text { cost } \\
\quad \text { ratio }\end{array}$ \\
\hline \multirow{2}{*}{$505 /$ E.B } & IWM & 1600 & 300 & 1800 & 3700 & 14080 & 10380 & 3.80 \\
\hline & FP & 2400 & 1500 & 1800 & 5700 & 15360 & 9660 & 2.69 \\
\hline \multirow{2}{*}{$156 /$ E.B } & IWM & 2000 & 1200 & 1800 & 5000 & 19840 & 14840 & 3.96 \\
\hline & FP & 2400 & 2400 & 2100 & 6900 & 23360 & 16460 & 3.38 \\
\hline \multirow{2}{*}{537 /E.B } & IWM & 1200 & 900 & 1700 & 3800 & 16640 & 12840 & 4.37 \\
\hline & FP & 2400 & 1800 & 1800 & 6000 & 20480 & 14480 & 3.41 \\
\hline \multirow{2}{*}{557 /E.B } & IWM & 1200 & 900 & 2400 & 4500 & 25600 & 21100 & 5.68 \\
\hline & FP & 2000 & 2400 & 3200 & 7600 & 30720 & 23120 & 4.04 \\
\hline \multirow{2}{*}{8 /W.B } & IWM & 1600 & - & 1800 & 3400 & 16640 & 13240 & 4.89 \\
\hline & FP & 2000 & 900 & 2600 & 5500 & 19200 & 13700 & 3.49 \\
\hline \multirow{2}{*}{17 /W.B } & IWM & 2000 & 900 & 2400 & 5300 & 16640 & 11340 & 3.13 \\
\hline & FP & 2400 & 1500 & 2400 & 6300 & 14080 & 7780 & 2.23 \\
\hline \multirow{2}{*}{479 /E.B } & IWM & 1600 & 900 & 2000 & 4500 & 14432 & 9932 & 3.20 \\
\hline & $\mathrm{FP}$ & 2000 & 1500 & 2000 & 5500 & 15680 & 10180 & 2.85 \\
\hline \multirow{2}{*}{ Dolatabad } & IWM & 1600 & 900 & 2500 & 5000 & 18240 & 13240 & 3.64 \\
\hline & FP & 2400 & 1200 & 2500 & 6100 & 20480 & 14380 & 3.35 \\
\hline \multirow{2}{*}{ Islam Kot } & IWM & 2400 & 600 & 1600 & 4600 & 16800 & 12200 & 3.65 \\
\hline & FP & 4000 & 1200 & 2000 & 7200 & 16640 & 9440 & 2.31 \\
\hline \multirow{2}{*}{ Fadda } & IWM & 1600 & 900 & 3000 & 5500 & 28160 & 22660 & 5.12 \\
\hline & $\mathrm{FP}$ & 3200 & 2400 & 3400 & 9000 & 30720 & 21720 & 3.41 \\
\hline \multirow{2}{*}{159 /W.B } & IWM & 1600 & 600 & 2800 & 5000 & 17920 & 12920 & 3.58 \\
\hline & FP & 2400 & 1800 & 2800 & 7000 & 23040 & 16040 & 3.29 \\
\hline \multirow{2}{*}{34 /W.B } & IWM & 1600 & 900 & 3500 & 6000 & 35840 & 29840 & 5.97 \\
\hline & FP & 2400 & 2100 & 3500 & 8000 & 35840 & 27840 & 4.48 \\
\hline
\end{tabular}

*Per irrigation cost: Rs 400 / acre, **Per spray cost Rs: 300/acre, ***Seed cotton value: Rs 32/ Kg 


\section{Conclusion}

The benefit / cost ratio was higher in all the IWM plots (managed by the FFS farmers) at all FFS sites as compared to Farmer Practice plots even by applying more number of irrigations and pesticides. The significant achievements were;

- About 250-300 farmers and thirty-one technical staff (Field Assistants and NGOs people) were empowered in water conservation strategies in cotton particularly at Vehari during the cropping season.

- The number of irrigations was cut down to $33.4 \%$ respectively in IWM plots in the overall twelve FFS sites in Vehari.

The capacity building of the farming community in water scouting strategies and the adoption of innovative water management tools in cotton ecosystem can enhance the water use efficiency and conserve the water resources for the future.

\section{Acknowledgments}

The authors wish to acknowledge the financial assistance provided by WWF-Pakistan. The author would also like to acknowledge the Agriculture Extension department district Vehari, Punjab for their field facilitation.

\section{REFERENCES}

[1] Agricultural Economics Research Institute (1996). The Hague, Netherland. 1996, No. 573, 58 pp; 22 ref.).

[2] World Agriculture toward 2015/2030. An FAO perspective: http://www.fao.org/docrep/005/y4252e/y4252e00.htm

[3] Population action international (1997). A second update on sustaining water, population and the future of renewable water supplies.

[4] Ministry of finance (2013). Pakistan Economic Survey. P 159 